\title{
Children of an Earth to Come: Speculative fiction, geophilosophy and
}

climate change education research

David Rousell

Education and Social Research Institute, Manchester Metropolitan University

Amy Cutter-Mackenzie

School of Education, Southern Cross University, Australia

Jasmyne Foster

Banora Point High School, Australia

For correspondence please contact David Rousell at david.rousell@scu.edu.au 


\section{Children of an Earth to Come: Speculative fiction, geophilosophy and climate change education research}

Over the last three years, the Climate Change and Me project has mapped children and young people's affective, creative and ontological relationships with climate change through an emergent and child-framed research methodology. The project has involved working with 135 children and young people from across Northern NSW, Australia as co-researchers responding to the rapidly changing material conditions of the Anthropocene epoch. In this paper, we position speculative fiction as a mode of creative research which enabled the young researchers to inhabit possible climate change futures. This node of the Climate Change and Me research was initiated by co-author Jasmyne, who at the time was a year seven student at a local high school. Through an ongoing series of visual and textual posts on the project website, Jasmyne created an alternate world in which children develop mutant forces and bodily augmentations that enable them to resist social and environmental injustices. Drawing on these visual and textual entries in dialogue with Deleuze and Guattari's geophilosophy, we consider ways that speculative fiction might offer new conceptual tools for a viral strain of climate change education that proliferates through aesthetic modes of expression.

Keywords: Climate change education; Anthropocene; speculative fiction; geophilosophy; participatory research.

\section{Introduction}

This paper addresses the need for new approaches to climate change education that are responsive to the rapidly changing conditions of the Anthropocene epoch, a time in which humanity has become a geophysical force that is fundamentally altering the Earth's ecological systems (Steffen at al, 2015). As typified by accelerating rates of climate change, ocean acidification, species extinction, human population growth, ubiquitous computation, and biotechnological interventions in life processes, the Anthropocene signals a time in which the ontological distinctions between humanity, technology, and nature have become blurred, if not completely indiscernible (Braidotti, 2013; Haraway, 2016; Lee, 2013). As Morton (2013, p. 101) further argues, the age of the Anthropocene 
calls for "a profound upgrade of our ontological tools" in light of massively distributed geo-traumatic events such as global warming, radioactive contamination, and the mass extinction of plant and animal species. Within this critical posthumanist framing, "ontological tools" are understood in terms of speculative concepts, practices, methods, devices, designs, artworks, technologies, experiments, and fictions that can "help us rethink the basic unit of reference for the human" in the Anthropocene, "along with the basic tenets of our interaction with both human and non-human agents on a planetary scale" (Braidotti, 2013, p. 5).

In this paper, we specifically work to develop speculative fiction as an ontological tool that can enable children and young people to imagine possible worlds in response to the challenges of climate change, and more broadly, the changing material conditions of living in the Anthropocene. In doing so, we draw on participatory research undertaken in the Climate Change and Me project, which has mapped children and young people's affective, creative and ontological relationships with climate change over the last three years. This has involved working with 135 children and young people from across Northern NSW, Australia as co-researchers responding to the rapidly changing material conditions of the Anthropocene epoch. The artworks, essays, videos, photographs, poems and fictional works created through this research were assembled into a public touring exhibition in 2015 , and also provided the resources for a transdisciplinary climate change curriculum currently being implemented in regional primary and secondary schools.

One of the major contributions of this research has been the collective reconceptualisation of climate change education as a transdisciplinary field of inquiry that integrates concepts and practices from the arts, humanities and sciences. Speculative fiction has emerged over the course of our research as an ontological tool in this regard, particularly in its ability to open up new possibility spaces for thinking, feeling and 
experiencing climate change outside of anthropocentric imaginaries insisting on human dominance over nature.

In the sections below, we firstly offer a brief account of the field of climate change education, focusing on the need to develop new modes of practice that are responsive to the changing material conditions of the Anthropocene. This is followed by an account of speculative fiction as both an ontological tool and a literary genre, drawing on the work of writer Margaret Atwood (2004) along with Gilles Deleuze and Felix Guattari's (1986) concept of a 'minor literature' that works between the majoritarian regimes of Art, Science, Technology, Philosophy and Education. The following section addresses the relationship between speculative fiction and geophilosophy as creative modes of resistance that are responsive to the geo-traumatic events of the Anthropocene. We then offer a series of visual and textual "entries" composed by co-author Jasmyne, one of the students who participated in the Climate Change and Me project. As a creative response to climate change and the challenges of the Anthropocene epoch more broadly, Jasmyne used the Climate Change and Me online social media platform to create a work of speculative fiction populated by aberrant children who develop earthly forces and bodily capacities. In the final sections of the paper, we conduct a geophilosophical analysis of Jasmyne's creative works to explore how speculative fiction might re-orientate climate change education as a mode of "resistance to the present" (Deleuze \& Guattari, 1994, p. 99). We also draw on examples of how Jasmyne's fictional world infected the experiences of other children who participated in the project, leading us to propose a distinctly viral approach to climate change education which proliferates through speculative and aesthetic modes of expression. 


\section{Re-Thinking Climate Change Education}

In recent years it has been widely acknowledged that innovative and effective forms of climate change education are needed for children and young people worldwide, who will be forced to grapple with the uncertainties of climatic instability brought forth by previous generations (Kagawa \& Selby, 2010). Climate change education, however, remains a relatively nascent and under-theorised area of inquiry as considered independently from more established fields such as environmental education, science, technology, engineering and mathematics (STEM) education, and education for sustainability (Laessoe et al, 2009). Existing climate change education research has tended to focus on children and young people's scientific knowledge of climate change, often describing it as limited, erroneous and highly influenced by mass media (e.g. Shepherdson et al, 2009). A number of studies, however, suggest that scientific knowledge-based approaches have been largely ineffectual in altering the attitudes and behaviors of children and young people towards climate change (e.g. Brownlee, Powell \& Jeffrey, 2013; Devine-Wright, Devine-Wright, \& Fleming, 2004; Dijkstra \& Goedhart, 2012). Research has also indicated that cognitive increases in scientific knowledge about climate change has shown little to no correlation with changes in environmental attitudes or behaviour in the wider population (e.g. Kempton, 1997). Selby and Kagawa (2010) even observe a trend towards climate change skepticism and denial in mainstream science education programs. These authors specifically target science education as complicit in framing climate change "as an issue calling for a scientific or technical fix rather than as a pathology of an ethically numb, inequitable and denatured human condition" (p. 42).

These observations reflect the haunting presence of scientism in the institutional framing of climate change education, a presence that continues to position scientific knowledge as a more valued source, object and aim of education than other practices or 
forms of knowledge (Somerville \& Green, 2012). In attempting to bracket out science as a rarefied, empirical and superior knowledge practice that can be dissociated from cultural, social and political contamination, scientism has the paradoxical effect of "shutting one's ears to what is most interesting about science as such", namely its capacity to evoke speculation, wonder, creativity, and social change (Morton, 2016, p. 29). As scholars in the field of science and technology studies (STS) have vigorously demonstrated, acknowledging the political, aesthetic and speculative dimensions of science can reveal the ways that empirical results are actually generated through "a dynamic set of open-ended practices iteratively refined and reconfigured" (Barad, 2007, p. 167). STS thus provides a rigorous underpinning for innovative approaches to climate change education which acknowledge that "empirical science and rational discourse are largely continuous with other ways of feeling, understanding, and engaging with the world... [including] art, myth, religion and narrative" (Shaviro, 2015, p. 13).

In challenging binary oppositions between natural and cultural phenomena, the rise of STS in conjunction with the onset of the Anthropocene has acted like a "storm on thought" in the fields of environmental education, sustainability education and STEM education, calling into question many historical "presumptions, logics and methods of reason" and forcing these fields to re-evaluate "what really matters" (Payne, 2016, p. 169, emphasis in original). The Climate Change and Me project has contributed to this "storm on thought" by working with young people as co-researchers in mobilising educational practices that operate outside of anthropocentric and scientistic frameworks. Speculative fiction has emerged in this project as a salient and powerful mode of practice for undertaking such work, as it has enabled children and young people to create and inhabit fictional worlds and personas that are both attuned and responsive to the rapidly changing conditions of life in the Anthropocene. 


\section{Speculative Fiction as a Minor Literature}

Increasingly, speculative fiction is being cited as an ontological tool for exploring the philosophical, educational, artistic, and political implications of the Anthropocene in response to posthumanist and postanthropocentric concerns (see, for instance, Ghosh, 2016; Gough, 2015; Haraway, 2016; Morton, 2013; Shaviro, 2015; Weaver, 2010). In responding to posthumanist concerns, speculation is deemed necessary to imagine an education that "did not insist on human superiority and dominance and that did not disavow the human's ecological entanglements" (Snaza \& Weaver, 2015, p. 3). Speculation also becomes necessary when interpreting the implications of new technologies and scientific findings. Contemporary biology, for instance, suggests that plants, bacteria and slime moulds have the capacity for "experience" and are able to make "decisions", but speculation is required to imagine what the qualitative experience of these organisms would actually consist of (Shaviro, 2014, p. 88). Such ethological speculations are also being brought to bear on questions of artificial intelligence and bioengineered forms of life (Shaviro, 2015). It is in this sense that speculative fiction offers a unique and necessary tool for inquiring into the very nature of life in times of accelerating social, environmental and technological change, by tentatively enabling us to think beyond the constraints of human cognition and knowledge.

Yet speculative fiction also brings with it an extensive genealogy as a popular literary genre that incorporates an extraordinary range of imaginative and controversial works of fiction. In the broadest sense, speculative fiction can be described as a metagenera that subsumes science fiction, fantasy, magic realism, myth, fairy tales and horror within a multi-faceted mode of address. As the writer Margaret Atwood (2004, p. 513) explains, "speculative fiction may be used as the tree, for which science fiction, science 
fiction fantasy, and fantasy are the branches. The beast has at least nine heads, and the ability to eat all other fictional forms in sight, and to turn them into its own substance". Aliens, ghosts, vampires, cyborgs, hobbits, spaceships, gods and monsters all belong to the same speculative pantheon of nonhuman protagonists in this reading of the genre. A fiction, as Atwood (p.513) further notes, becomes distinct from a novel when it does not obey any of the literary constraints that place a novel in the phenomenological realm of human experience. This means that speculative fictions have the capacity to inhabit new bodies, landscapes and planets, propose radical changes in social and political organisations, and explore the very limits of human experience through graphic description and visualisation (p. 515).

These properties of speculative fiction provide a pragmatic starting point for its development as a mode of creative research, as well as an ontological tool in the context of climate change education. We are interested in how Atwood (2004) refers continuously to the exploration of possible worlds and social milieus, and also to the graphic ways in which those worlds are visualised and encountered. Yet it is speculative fiction's capacity to not only evoke but simulate possible worlds that makes it a radically empirical proposition for climate change education in the Anthropocene. As the philosopher Manuel Delanda (2011, p. 6) argues, such "simulations can play the role of laboratory experiments in the study of emergence [and] the structure of possibility spaces". When it becomes a form of immersive simulation rather than depiction, speculative fiction goes beyond metaphor and analogy to enable readers to explore other bodies, environments, and times that are virtual in their capacity to open up the potentials for new patterns of thought and behaviour.

As a way of experimenting creatively with the emergent structure of possibility spaces, speculative fiction offers an ontological tool for conducting thought experiments 
that are also grounded in the empirical reality of life itself (Shaviro, 2015). It is in this sense that speculative fiction can be located at the nexus between science, philosophy and art, while at the same time operating outside of each of these domains as what Deleuze and Guattari (1986) call a "minor literature". A minor literature is not concerned with the personal narratives of individual characters, but rather, with the social and political values and aberrant collectivities that are mobilised in and through the work itself (p. 17). Speculative fiction can thus be understood as a literature that operates in the cracks, interstices or "minor keys" between the majoritorian, State-controlled regimes of Art, Literature, Science, Technology, Philosophy and Education. Where these majoritarian or State regimes present a "constant and homogenous system", a minor literature operates through "subsystems ... seeds [and] crystals of becoming whose value is to trigger uncontrollable movements and deterritorialisations of the mean or majority" (p. 106). The artist and philosopher Erin Manning (2016, p. 1) offers a lucid account of this relationship:

The major is a structural tendency that organises itself according to predetermined definitions of value. The minor is a force that courses through it, unmooring its structural integrity, problematising its normative standards... The minor is a continual variation on experience. It has a mobility not given to the major: its rhythms are not controlled by a preexisting structure, but are open to flux.

In advancing speculative fiction as a minor literature that is open to flux, difference and the continuous variation of experience, we aim to hone its capacity to function as a critical and creative mode of educational practice in response to the 
Anthropocene's challenges. The following section further contextualises speculative fiction as a collective mode of political resistance in relation to Deleuze and Guattari's (1994) geophilosophical imaginary.

\section{Speculative Fiction and Geophilosophy}

As originally introduced by Nietzsche and further developed in the works of Deleuze and Guattari (1987; 1994), geophilosophy explores the entangled relationships between the composition of thought, territory and the Earth itself. Its starting point can be simply articulated in the proposition that "thinking takes place in the relationship of territory and the earth" (1994, p. 85). Territorialisation, in this sense, refers to the expressive process of marking out the conceptual, social and physical architectures that afford places for cohabitation, along with the associated capture of earthly environments and milieus (Deleuze \& Guattari, 1987, p. 311). Alternatively, deterritorialisation refers to the dissolution or abandonment of existing territories in order to form new assemblages through the ongoing variation of thought, movement, articulation, framing, and other modes of co-habitation. Where territorialisation harnesses the tendencies toward order, boundary, codification, structure, stability, habit and finitude, deterritorialisation harnesses the forces of chaos, disorder, variation, release, mobility, and infinitude. These differential forces function in iterative cycles, such that each territorialisation establishes the conditions for possible deterritorialisations, which in turn establish the potentials for reterritorialization under an altered set of ontological conditions or 'multiplicities'. Geophilosophy thus reimagines the nature of thought as a geologic process in continuous contact with the Earth itself, "as more of a movement of multiplicities that pertains to territories rather than a cognitive faculty restricted to already formed subjects" (Parrika, 2015, p. 21). 
Recently a number of scholars have explored the convergence of speculative fiction with geophilosophy as a mode of addressing the social and environmental traumas associated with petro-capitalism, climate change and the biopolitics of the Anthropocene epoch (Haraway, 2016; Shaviro, 2015; Woodard, 2013). Cyclonopedia: complicity with anonymous materials, for instance, is a work of theoretical fiction by the Iranian philosopher Reza Negerastani (2008) that offers a geophilosophical account of petroleum as both the living lubricant and narcotic of post-industrial world capitalism. Negerastani (cited in Woodard, 2013, p. 14) further describes geophilosophy as a response to the traumas that are inflicted on the earth under such regimes:

If geophilosophy is a philosophy that grasps thought in relation to earth and territory, then it is a philosophy that, perhaps unconsciously, grasps thought in relation to two traumas, one precipitated by the accretion of the earth and the other ensued by the determination of the territory. Whilst the former trauma lies in the consolidation of the earth as a planetary ark for terrestrial life against the cosmic backdrop, the latter is brought about by a combined geographic and demographic determination of a territory against the exteriority of the terrestrial plane and fluxes of populations of all kinds.

Negerastani's articulation of two distinct forms of geo-trauma is helpful, as it distinguishes between the plundering, sedimentation, ungrounding and stratification of the earth's ecologies to sustain unregulated economic growth, and the social control of geographic territories that ensures dependency on petro-capitalism into the future. The first geo-trauma has the effect of securing the ongoing capture, commodification and appropriation of the Earth's ecological systems and milieus by the petro-capitalist regime. 
Yet the secondary trauma involves the stifling of creative forms of thought and collective social action that might remediate environmental catastrophe by generating new ecologies of belonging and participation. This form of geo-trauma effectively traps individuals and societies within a present that appears both intolerable and insurmountable, such that we "continue to undergo shameful compromises" rather than exploring creative alternatives for future ways of life (Deleuze \& Guattari, 1994, p. 108).

It is in this sense that speculative fiction and geophilosophy converge as modes of "resistance to the present" that can "summon forth a new earth [and] a new people" which are lacking in our current world (Deleuze \& Guattari, 1994, p. 99). It is important, however, not to confuse the "new earth" and "new people" of geophilosophy with Romantic visions of an idealised utopia that somehow transcends ecological devastation and social injustice. While speculative fiction may offer "a resistance to the present in the hope of a better future", as Bogue (2011, p. 82) notes, "that future cannot be predicted, nor can its superiority to the present be assured". Speculative fiction does not offer a solution to geo-trauma or a prediction of future ideals, but an opening up of possibility spaces for collective thought experiments to occur (Shaviro, 2015). When coupled with geophilosophy, speculative fiction becomes an ontological tool for exploring the possibilities of new logics and geopolitical structures that are predicated on relational coexistence, creativity and difference as the basis for new forms of social belonging.

\section{Becoming Aberrant}

In the Climate Change and Me project, speculative fiction emerged as a creative research method that opened up spaces for children and young people to think and act differently in relation to climate change. This process was set in motion through the project's emergent research design and child-framed methodology (Barratt Hacking, Cutter- 
Mackenzie, \& Barrratt, 2013), which allowed us to work collaboratively with children and young people within a "co-research playspace" (Cutter-Mackenzie \& Rousell, 2014). Initially this involved hosting research training workshops in local schools, where students were introduced to the concept of the Anthropocene epoch and learned to conduct ethnographic interviews and observation, take field notes, and use creative practices such as drawing, photography, and video as educational research methods.

We also developed a customised and secure social media interface that enabled the young researchers to post and comment on each other's findings, as well as initiate their own small projects, discussions and games within a blogspace we called the " $\mathrm{CC}+$ Me Hangout" (see Figure 1). The children and young people were encouraged to take on fictional avatars and alternative identities within this online research space, and we also suggested that collaborative fictions could be used to explore different climate change futures and social responses.

\section{(c)}

\section{THE CC+ME HANGOUT!}

Back to The CC+Me Hangout!...

The beginning of the change- Aoi's story and yours (6 replies)

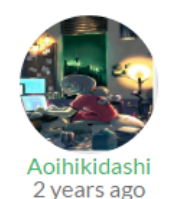

November 17 th 2014

Aoi's bio

Age: 14

Gender: boy

Hair: a almost neon blue, short messy

Clothing: casual mostly jeans baggy shirts and large hoodie jumpers and

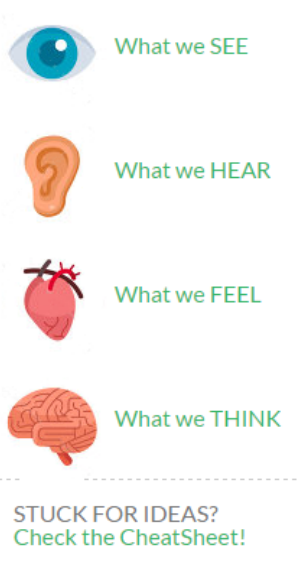

Figure 1. Screenshot from 'The CC + Me Hangout' showing Jasymyne's first entry introducing her avatar character Aoihikidashi, or Aoi for short. 
Co-author Jasmyne was a seventh grade student in a local high school that participated in several of the Climate Change and Me workshops at the university. Using the iPads provided for the research training activities, Jasmyne began developing a fictional character named Aoi through a series of textual and visual posts into the $\mathrm{CC}+$ Me Hangout space. This marked the first of an ongoing series of entries on the project website, as Jasmyne outlined the contours of an alternate world in which children develop mutant forces and bodily augmentations that enable them to resist social and environmental injustices. These children are labelled "Aberrants" as opposed to "Normals", and are hunted down by cyborgs capable of scanning and annihilating those with anomalous genetic mutations. Central to Jasmyne's story is the character of Aoi, who discovers after a near-death incident that anything he draws in his sketchbook can come to life for a time.

Together we witnessed the emergence of this speculative narrative as it continued to evolve in tandem with the actual research events. The timeframe of the entries begins in November 2014, the date of the initial research training workshop, and follows the adventures of the characters and transformations of the earthly environment into December 2047. It is through the meticulous extension of characterisation, timescale, and geographical location that this fictional world becomes palpable as creative research, while simultaneously addressing critical posthumanist concerns: the mutations of new forms of life that exceed the human; the erasures of memory through geo-traumatic psychosis; the arbitrary destruction of human and nonhuman entities; the (un)desired affordances and responsibilities of aberrant neurodiversity; the rapid proliferation of nano-technologies; and the spectral hauntings of cyborg politics. 
Jasmyne's creative research initiative also offered an opportunity for ongoing collaboration with other young people and co-author David, who took on fictional avatars and posted their entries into the Hangout space on a weekly basis. Over time, the entries developed into a non-linear collaborative narrative in which the voices of individual authors became entangled, and at some points, indistinguishable. These entries were then shaped into an illustrated short story called "The Beginning of the Changes" in the coedited book of children and young people's research that accompanied the travelling Past Now Future exhibition (Rousell \& Cutter-Mackenzie, eds., 2015). The following section offers a series of abridged entries from "The Beginning of the Changes", as illustrated with Jasmyne's characterisations and sketches. The entries are presented in the order they were submitted to sustain the non-linear movement between fictional voices, places and timescales that emerged through the collaborative process.

\section{Entry 1: November $17^{\text {th }} 2014$}

NAME: AOI

AGE: 14

GENDER: BOY

HAIR: AN ALMOST NEON BLUE, SHORT, MESSY

Clothing: CASUAL, MOSTLY JEANS, BAGGY SHIRTS AND LARGE HOODIE JUMPERS AND LARGE SNEAKERS

ACCESSORIES: ONE SILVER EARRING AND A GOLD FAMILY RING

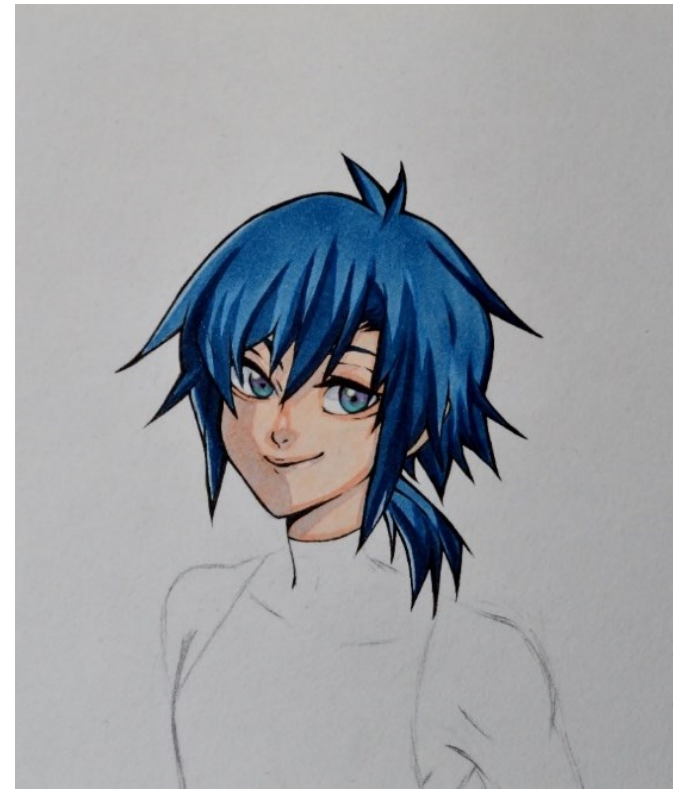

A room that looked like a bomb hit it, clothes scattered messily on the floor. A bed that didn't look much like a bed, more like a table with sketchbooks scattered on the end. A 
bag crumbled in the corner with a clatter of key chains and bulging with the shape of a lunch box. This was Aoi's room.

Aoi was interested in the workings of the universe and was a full blown realist. He had always cared about the earth's geological problems and biological workings. But when he thought about it, helping scientists in the lab might be difficult for someone who just loved to draw so much. But just when he thought of giving up on science and becoming some generic worker for a large company he found out about climate change. He decided to search for some information and he was so strongly taken by the topic that he began to post about it on social media. Aoi was so interested in climate change and he wanted people to become more aware, but how could he make a difference?

He was only a child in the eyes of the public, not likely to be taken seriously.

\section{Entry II. November $18^{\text {th }} 2047$}

NAME: ELBERETH

AGE: 47

GENDER: WOMAN

HAIR: WHITE WITH SLIGHT STREAKS OF BLUE

Clothing: OLD CLOTHES WITH HOLES THAT HAVE BEEN EATEN BY MOTHS

ACCESSORIES: TWO PEARL EARRINGS AND A FOX MASK THAT SHE KEEPS IN A BOX UNDER HER BED

COMPANIONS: A WISE AND TIRED OLD DOG NAMED TURIN

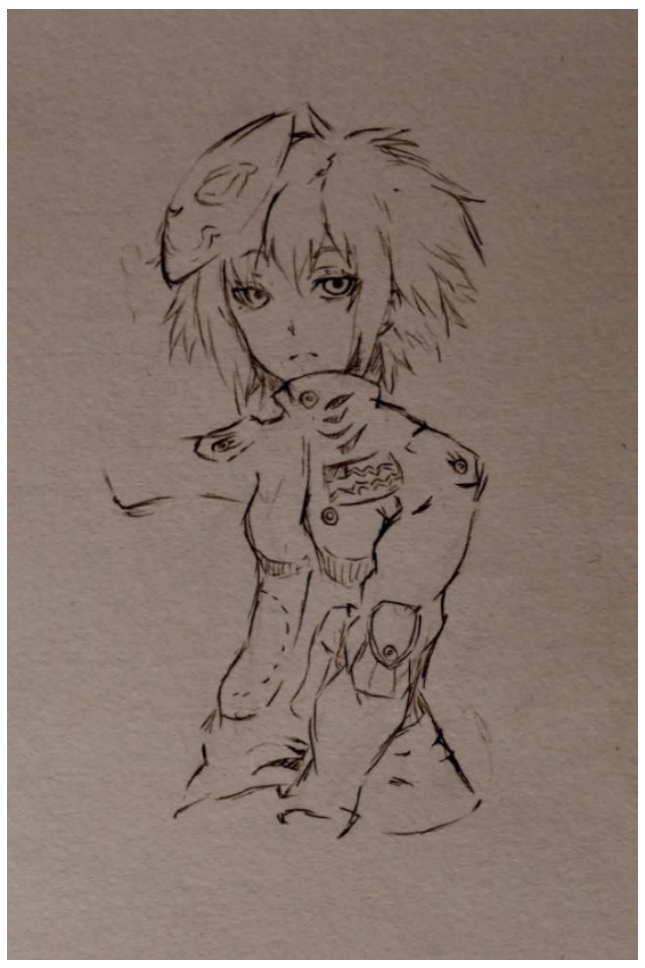


The wind blows in the door again and I can hear the rush of the water breaking on the cliffs below. Turin barely moves at all, he just opens one eye and looks at me as if I've created the disturbance. The air is full of frozen salt crystals, they bite my cheek as I brace the door closed with the last of my heavy books. Soon I'll have used up all my esoteric books for fire-starters and everything in them will probably be forgotten. It's been too long since I've felt the power of the earth in my fingertips, the electric current that turns the waves away from the valley below. Now I lack the strength, and the memories flow back like the tides that nobody can stop from washing in.

But what's that? Turin is up, stretching and starting to growl at the same time. I hope it's not those raiders again, last time they cleared me out of rice and oats faster than I could get out of my rocking chair. Something is scratching at the wooden door. I grab the knife from next to the cutting board where I'd been chopping kale from the garden. It's only a bread knife, but it's better than nothing.

"Who's there!" I say in my deepest, scariest voice. I open the door just a crack, and can just make out the shadow of a person against the pelting wind and rain. It's a child, no a man, with a face that looks so familiar and yet cloaked in shadow. I open the door all the way and he falls into my cabin, drenched and exhausted on the floor.

"Who are you?" I say sternly with the kale knife gripped steadily in my hand.

"Aoi," the voice faintly replies.

\section{Entry III. December 5th, 2014}

All the kids at high school had been invited to the research workshop about climate change. Aoi found himself doing a practice interview with a talkative girl named Elbereth. "I think the Earth has already transitioned into a new geological era," she was saying. 
"Humans have become like this viral force that's affecting every ecosystem on the planet."

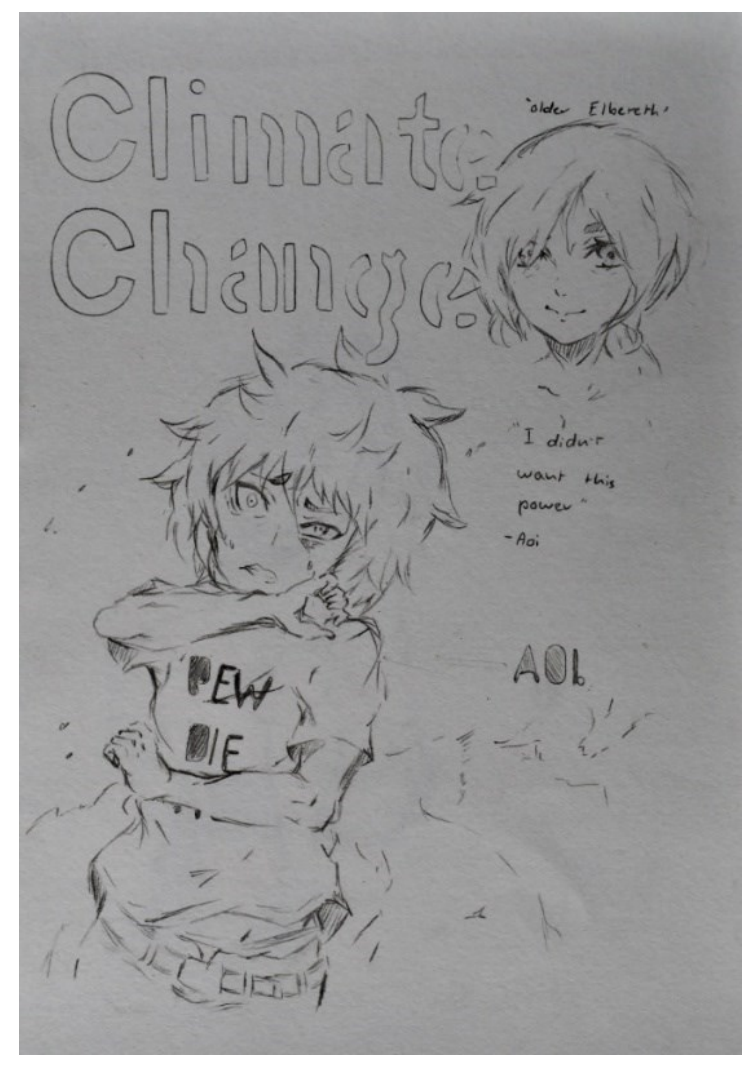

That afternoon after school they went for a walk in the old forest behind the school, Elbereth with her notebook writing stories and Aoi with his sketchbook drawing the creatures that sprang into his mind. They came to a rushing stream that had swollen with water after the recent flood. Aoi started to make his way across the stream on the wet log. Suddenly, he slipped on a patch of moss and fell into the rushing water. His head hit a rock and his body was swept downstream.

Elbereth ran along the bank as fast as she could, but when she finally caught up to him his body was cold and lifeless. Desperate, she placed her hands on his heart and summoned all the power in her body to put warmth into him. She felt a vital energy enter her body from the forest floor, pulsing through her arteries like blood, producing heat that made her skin burn as if touching flames. Suddenly Aoi sputtered and sat up, looking at her with wild eyes.

Later they found Aoi's sketchbook soaked and lying upside down alongside the rushing stream. It was moving slightly. Aoi picked up the sketchbook, and jumped back in surprise- underneath it was a frog-like creature with pale translucent wings. It jumped onto the nearest rock, then flapped its wings and flew away. 
With trembling hands, Aoi turned over his notebook to the page he had been working on before he fell into the stream. There on the page was the very creature they had just seen fly away- an amphibian with the wings of a dragonfly. Aoi looked at his drawing hand in amazement.

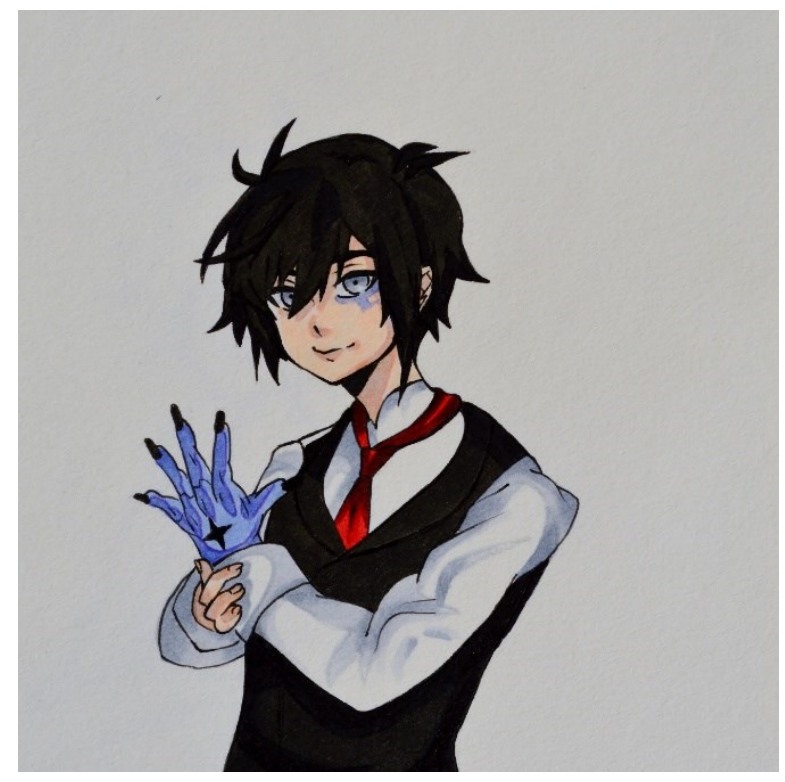

The flesh had changed to a strange blue colour, and the nails had become like black claws.

\section{Entry IV. March 23, 2021}

The staff stood silently in the centre of the task force building. Nerves were high. It was rare that the entire task force would be asked to meet unscheduled. Everyone was tense, even senior detective Shinohara looked tense. The eerie silence continued for another few seconds until Shinohara broke it. "Task force, we are gathered here today to see the latest technology from Astral Labs to combat the ever-growing aberrant infestation. I will now hand the floor over to Professor Arima."

A small man emerged from the other side of the room. He wore a white coat and carried a brief case with him. He stood next to Shinohara in the centre. "This," Arima said pointing to the brief case, "is the future of aberrant hunting. It will allow you to find aberrants and neutralise them faster than ever before. Here, allow me to demonstrate."

Professor Arima pushed down on the handle of the brief case. The case split in two revealing a block of metal slowly taking on humanoid form. "This is Shudon, the 
latest in aberrant hunting technology. This is military funded weaponry with a built in psycho-pass able to scan aberrants to a fifty meter radius; all that is required is a sample of blood. With on-board facial recognition system and a fully equipped medical kit Shudon is by far the most powerful weapon for aberrant extermination ever invented."

\section{Entry V April 15 ${ }^{\text {th }} 2021$}

Elbereth buried herself into her coat. She walked steadily, looking at the graffiti scribbled across the side of the buildings. Many were political slogans so she paid no attention to the messages. She soon came across the task force headquarters where wanted posters of criminals were pasted along the side of the discoloured brick walls. But criminals weren't the only ones with wanted posters.

The wall had a section for "aberrants". This was the dim name that the humans had classified those with powers under. She walked over to the wall and looked for her wanted poster. It didn't take long to find a poster of her with her mask on. It was labelled 'Firefox'. Elbereth could feel heat emanating from her hands. Dangerous, volatile, and will kill without remorse? They were all lies!

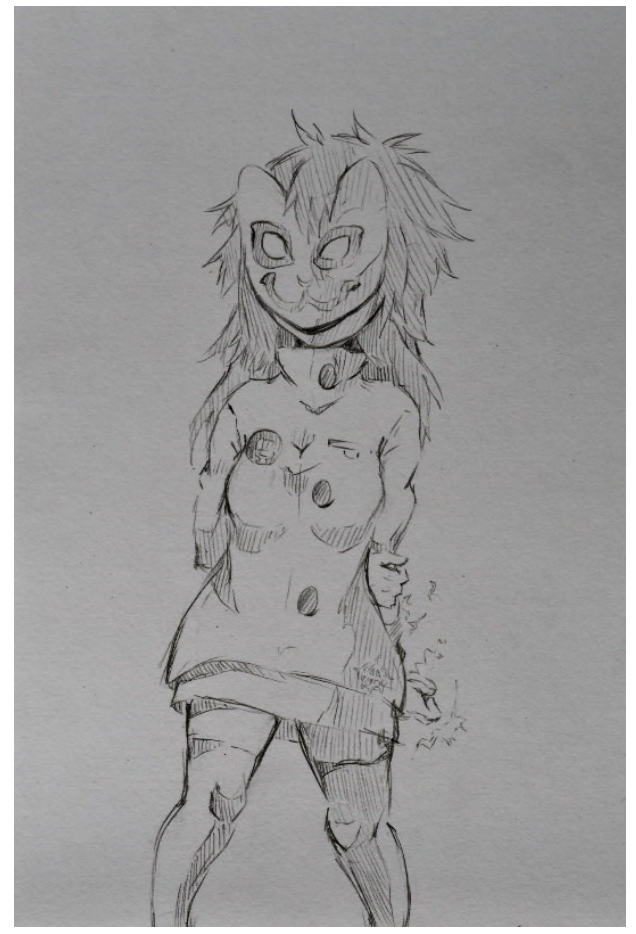

She grasped a corner of the poster and tore it down from the wall, using the heat emanating from her palm to set the poster ablaze with fire. 


\section{Entry VI. November $20^{\text {th }} 2047$}

I wake in my rocking chair to the smell of oatmeal cooking over the fire. No, it wasn't all a dream. My oldest friend Aoi is crouching over the flames, stirring the pot with a long wooden spoon. He turns and looks at me, the piercing clarity returning to his eyes by the second. years?"

"Aoi," I say. "I can't believe you're here. How did you find me after all those

"There was just this map, Elbereth, a map in my mind. And I followed it to your door. But tell me, please. I think I've lost my memory for thirty years. Are we the only ones left in the world? Did my visions actually come true?"

"Many came true, and we are deep in the Changes as they have spread across the Earth," I explain. "The power grid shut down five years ago, and the Netscape was destroyed not long after. Wireless mesh networks still communicated for a while- I have a node here that kept me updated with the latest information until it rusted out from the saltspray last year. Transmissions were coming through from communities up and down the coast that had formed their own collectives, rebuilding their towns and villages to adapt to the Changes. The cities are apparently lawless and mostly deserted. People like us have been helping- using our earth powers to protect and heal the communities- and fighting off the raiders when we need to."

\section{Entry VII. December $1^{\text {st }} 2047$}

"Aoi, the food's ready".

"I'll be out as soon I can. Just have to finish this," I say softly, trying not to show Elbereth how desperate I am to finish the drawing. Drawing is the cure to my 
illness. When I have a sketch book near me I feel my power and memories rushing back. Drawing makes me feel invincible. It's like I draw power from the image, and the better the image the better I feel.

Then we hear a ghostly rapping on the door. I freeze, while Turin barks furiously at the door. "Who's that?" Elbereth calls from the kitchen. I can hear her kale knife coming down with force onto the chopping board.

“Come out meat," a voice calls tonelessly. I feel my heart skip a beat. I've heard that voice before. Then the door breaks open and an arm of steel emerges through the hole in the wood. The hand draws back and a pulsing robotic eye peers through. "I found you Anthropos!" the toneless, mechanical voice calls out.

I bolt up, sweat pouring down my face. "We have to leave," I mutter nervously, my voice cracking like glass as I speak.

Elbereth just stares. "Who is that Aoi?" The metal hand is scraping furiously at the wood like a caged animal.

“It's Shudon. He's finally found us." I start flipping through my sketchbook, desperately searching for the right page.

\section{Setting the Coordinates for Experimentation}

While the entries above offer numerous possibilities for analysis and educational application, in this paper we prioritise the development of speculative fiction as an ontological tool for re-imagining climate change education. In adopting the theoretical imaginary of geophilosophy for this purpose, our analysis focuses on the capacity for speculative fiction to deterritorialise the concepts and practices of climate change education through the production of new territorial assemblages as functions of creative expression. Deterritorialisation, in this geophilosophical sense, occurs when 
"expressiveness no longer functions strictly for the territory but expresses a becoming ... a new, unforeseen territorial assemblage" (Young, 2013, p. 307).

We begin our analysis by acknowledging that the emergent, existential territories generated through these entries are not generic or universal but "contingent and specific", with particular sets of coordinates that support the structure of the social world it produces (Bogue, 2011, p. 82). More specifically, we see the entries operating as an open constellation or topological series that de- and reterritorialises the actual events of the Climate Change and Me research, including the research workshops, the collaborative fieldwork, the online social media space of 'the Hangout', and the ThinkTank analysis workshops where other children began to write their own characters into the work. In short, the entries above do not simply "float into the world from nowhere" (Whitehead, 1978, p. 244), but are intimately connected with the spatial and temporal coordinates of the research itself as a series of events that continue to take place in the actual world.

This speculative-empirical proposition allows us to understand the production of the narrative as a process that generates new experiential openings or nodes in a series of events that are already in motion. By introducing new nodes of inception into the series, the narrative sets the methodological "protocols of experimentation [which] provide a certain scaffolding for resistance" through creative fabulation (Bogue, 2011, p. 82). As Deleuze and Guattari (1994, p. 110) suggest, the act of creation is inherently an act of political resistance that responds to the constraints of the present. Indeed, it is this very resistance to the material and discursive constraints of the research itself that enabled Jasmyne's visual and textual entries to become "reference points for an experiment that exceeds our capacities to foresee" (Deleuze \& Parnet, cited in Bogue, 2011, p. 83). 


\section{The Beings of Fiction}

It is through this experimentation with possible futures that the entries enable the geo-traumatic effects of climate change to become palpable through the experiences of Aio and Elbereth, as what we call "children of an Earth to come". Both Aoi and Elbereth are what Latour (2013, p. 251) calls "beings of fiction", conceptual personae or "actants" who are "made of the same materials, the same figures" as the apparatuses of scientific inquiry, or the conceptual schematics of philosophy. Such fictional characters exert an influence beyond the worlds of the imagination to reveal the speculative and compositional nature of science, technology, medicine, law and every other practical mode of existence (p. 249). "How can we speak about remote galaxies, particles of matter, upheavals of mountains, valleys, viruses, DNA or [climate change]", Latour asks, "without having at our disposal characters apt to undergo such adventures?" (p. 250, emphasis in original). In the entries above, our two characters take us "elsewhere, into another space, another time, another figure or character or atmosphere" (p. 246), revealing to us the internal and external consistencies of new aesthetic milieus that are also intimately connected with the concrete challenges of our current existence.

Yet Aoi and Elbereth are not pure, ideal or transcendent characters who serve a moralistic or instrumental function, but aberrants, mutants, members of "an oppressed, bastard, lower, anarchical, nomadic and irremediably minor race" (Deleuze \& Guattari, 1994, p. 109). Despite Aoi's visionary capacity to understand the "earth's biological and geological workings", he remains "only a child in the eyes of the public, not likely to be taken seriously". The minoritarian status of these characters is therefore emblematic of the broader marginalisation of children and young people in today's political economies as 'minors', in which they are accorded very little agency on political issues that have a direct bearing on their lives. Much like Elbereth and Aoi, children and young people who 
wish to enact their political beliefs on climate change have very little choice but to become "aberrants" themselves. Moreover, such aberrancy is described in the entries as an "infestation" which must be "exterminated" by means of biometric surveillance technologies such as facial recognition, psychological scanning, and biogenetic identification.

\section{Geomorphic Mutations and the Decaying Earth}

As beings of fiction, it is Aoi and Elbereth's minoritarian resistance to the normativity of an intolerable present that constitutes the source of their power and intensity, as expressed through their openness to the chaosmic forces of the Earth under the conditions of geo-trauma. Both Aoi and Elbereth are transfigured by the geological forces of creativity unleashed from the Earth itself, and which deterritorialise and intensify their biological structures and bodily capacities to respond to climate change. We suggest that these are geomorphic rather than anthropomorphic mutations, in the sense that the characters transform in 'rhizomatic connection with the earth (the forces of territorialisation and deterritorialisation)' (Bonta \& Protevi, 2004, p. 92). Hence, the characters' increased bodily capacitations and intensities are not deliberate, intentional, or filiative in any human sense, nor are they the result of a linear, hereditary or genealogical evolution towards greater functionality, mastery, or well-being. Rather, these mutations can be understood geophilosophically in terms of a dark, machinic, and creative involution (Deleuze \& Guattari, 1987, p. 238), as an attunement to "planetary decodings" that release becomings which are excessive, unstable, and contagious in nature (Wallin, 2015, p. 139). While Aoi's drawing hand is afforded the capacity to bring images to life, it also becomes monstrous and infected by his sensitivity to the traumas being inflicted on the Earth. 
In taking up this dark line of ecological thought, the Earth is no longer figured as the source of wellness and abundance but as an occulted, diseased, and ungrounded series of decaying and dysfunctional systems (Negerastani, 2008; Wallin, 2015). As such, the onset of Aoi's mutant capacitation results almost immediately in a melancholic endarkening of his affective state, followed by three decades of amnesia as he is pursued to the ends of the earth by Shudon, a merciless automaton propelled by the technoscientific regime. Elbereth's initial optimism and "green" revolutionary spirit quickly give way to a reclusive life of meagre survival, as her elemental powers dwindle with the onset of loneliness and ennui. Rather than being gifts of earthly connection or transcendence, the characters' mutations affect them more like a curse, an infection, an addiction, or a virus, for which their aberrant creativities and strange alliances offer the only cures.

\section{Towards a Viral Education}

Through our geophilosophical analysis of the entries above, we identify a specifically viral strain of climate change education that offers certain propositional openings for practical approaches in the classroom. This urges us to consider the ways that global warming, nuclear waste, water contamination, or other ecological catastrophes might enter into the classroom not only as discursive topics, but as transcorporeal forces which pass through and infect the very structures of bodies (Alaimo, 2010). This transcorporeal conception of climate change education as virus or contagion therefore differs from developmental, genealogical, or what Deleuze and Guattari (1987, p. 12) might call "arborescent" modes of teaching and learning that are predicated on the cognitive development of the individual student. 
For our purposes here, the viral potentials of such a climate change education can be illustrated through the narrative's ongoing infection of the learning experiences of other children. As part of the climate change curriculum which we trialled in local schools in 2016, over 150 students both read and responded to Jasmyne's narratives in a number of different ways. For example, 35 children wrote themselves into the story by creating their own "Aberrants" with mutant abilities such as:

- controlling dark matter, time, and darkness;

- appearing completely emotionless in the face of fear;

- changing emotions at will and infecting those around me with my mood;

- shapeshifting into any animal or plant;

- putting thoughts into other peoples' heads;

- enabling people to meet themselves and truly feel others;

- manipulating and controlling media communications; and

- changing or redirecting matter in the general vicinity

While we lack the space here to analyse the implications of these responses, we note that these abilities clearly resonate with both the affective and material inflections of Jasmyne's original entries. This is evident in the children's focus on the potential transfigurations of both matter and life, as well as an emphasis on the manipulation of emotional states as conditioned by the narrative's "dark" ecological aesthetic.

These contagious qualities of Jasmyne's narrative were also reflected in a range of other creative responses crafted by students in other schools. Of particular note was the development of an interactive multimedia platform under the rubric of Atlantic Adaptation Theory (AAT). As conceived, designed, and managed by an enterprising 
collective of year-six students, the AAT web platform focused on theorising the possibilities for biological adaptations to climate change, including explorations of biophysical mutation, breath analysis, space exploration, organic terraforming, bioluminescence, and hypnosis, among many other speculative areas of inquiry. Participation in the AAT platform was through a game-based system in which students' avatars advanced in rank (from apprentice, to researcher, to theorist) based on the quality and extent of their research contributions. The contagious influence of Jasmyne's original narratives on the AAT platform can thus be seen in the students' development of a realtime collaborative architecture, along with the platform's focus on bio-hacking, bodily mutation, and esoteric rituals rather than techno-scientific "solutions" to environmental crisis. While impossible to quantify, this contagious proliferation of affective resonances from one emergent node of the research to another ultimately presented one of the most salient and surprising findings of the larger Climate Change and Me project.

\section{Conclusion: Staying with the Earth}

In conclusion, we return to the question of how speculative fiction might be operationalised as an ontological tool for a climate change education that is responsive to the challenges of the Anthropocene. Based on our geophilosophical analysis of data from the Climate Change and Me project, we suggest that speculative fiction can enable young people to respond to climate change through creative modes of education that catalyse "the emergence of new possibilities for life through resistance to the present" (Bogue, 2011, p.88). As noted in the previous section, this constitutes a viral approach to climate change education and its associated research that finds its creative expression in the proliferation of experimental practices, alliances, architectures, and spatio-temporal nodes of inception. While this approach aims to foster creative modes of resistance to a 
present that appears both injust and intolerable, it also maintains "a posthumanist ethical commitment to stay with the occulted life of this planet" without aspiring to transcendence, escapism, or any other "way out" (Wallin, 2015, p. 144, emphasis in original).

In closing, speculative fiction has the potential to empower young people to respond to the challenges of the Anthropocene "through aesthetic modes of address which are not confined by an adherence to moral, scientific or discursive regimes of expression" (Turpin \& Davis, 2015, p. 4). As our research with children and young people has shown, speculative fiction does not function to refute or eschew science, morality, or discourse, but rather creates a new aesthetic milieu in which these elements might be encountered differently, on terms that are affective and ontological rather than cognitive and epistemological (Shaviro, 2015). We further propose that such speculative and aesthetic milieus have the capacity to support children as practitioners capable of producing finely tuned research outputs that are steeped in the culture of the minor, the aberrant, the nomadic, and the geomorphic. Crucial to this argument is the reconsideration of children as researchers, as artists, as writers, as scientists, and as philosophers who are intimately attuned to planetary changes. We welcome this as a distinct opportunity for children and young people to actively re-shape the very nature of climate change education through such active speculation and the creation of possible futures.

\section{References}

Alaimo, S. (2010). Bodily natures: Science, environment, and the material self. Bloomington: Indiana University Press.

Atwood, M. (2004). The Handmaid's Tale and Oryx and Crake "In Context". Modern Language Association, 119 (3), pp. 513-517. 
Barad, K. (2007). Meeting the universe halfway: Quantum physics and the entanglement of matter and meaning. Durham, NC: Duke University Press.

Barratt Hacking, E., Cutter-Mackenzie, A., \& Barrratt, R. (2013). Children as active researchers: The potential of environmental education research involving children. In R. Stevenson, A. Wals, M. Brody, \& J. Dillon (Eds.), The Handbook of Research on Environmental Education (pp. 438-458). Washington: American Educational Research Association.

Bogue, R. (2011). Deleuze and Guattari and the future of politics: Science fiction, protocols and the people to come. Deleuze Studies, 5, 77-97.

Bonta, M., \& Protevi, J. (2004). Deleuze and geophilosophy: A guide and glossary. Edinburgh, UK: Edinburgh University Press.

Braidotti, R. (2013). The posthuman. Cambridge, UK: Polity Press.

Brownlee, M., Powell, R. B., \& Jeffery, H. C. (2013). A review of the foundational processes that influence beliefs in climate change: Opportunities for environmental education research. Environmental Education Research, 19(1), 120.

Cutter-Mackenzie, A., \& Rousell, D. (2014). Climate change education in Anthropocene and Holocene times. Invited symposium presentation at Australian Association of Educational Research conference, Brisbane, Australia.

Delanda, M. (2011). Philosophy and simulation: The emergence of synthetic reason. London, UK: Continuum.

Deleuze, G., \& Guattari, F. (1994). What is philosophy? New York, NY: Columbia University Press.

Deleuze, G., \& Guattari, F. (1987). A thousand plateaus: Capitalism and schizophrenia (B. Massumi, Trans.). Minneapolis, MN: University of Minnesota Press.

Deleuze, G., \& Guattari, F. (1986). Kafka: A minor literature. (D. Polan, Trans.). 
Minneapolis, MN: University of Minnesota Press.

Devine-Wright, P., Devine-Wright, H., \& Fleming, P. (2004). Situational influences upon children's beliefs about global warming and energy. Environmental Education Research, 10(4), 493-506.

Dijkstra, E. M., \& Goedhart, M. J. (2012). Development and validation of the ACSI: Measuring students' science attitudes, pro-environmental behaviour, climate change attitudes and knowledge. Environmental Education Research, 18(6), 733-749.

Ghosh, A. (2016). The great derangement: Climate change and the unthinkable. Chicago: University of Chicago Press.

Gough, N. (2015). Undoing anthropocentrism in educational inquiry: A Phildickian space odyssey? In Snaza, N., \& Weaver, J., Posthumanism and Educational Research, pp. 151-166. New York, NY: Routledge.

Haraway, D. (2016). Staying with the trouble: Making kin in the Cthulucene. Durham, NC: Duke University Press.

Kempton, W. (1997). How the public views climate change. Environment, 39(9), $12-21$

Læssøe, J., Schnac, K., Breiting, S., \& Rolls, S. (2009). Climate change and sustainable development: The response from education. International Alliance of Leading Educational Institutes.

Latour, B. (2013). An inquiry into modes of existence: An anthropology of the moderns (C. Porter, Trans.). Cambridge, MA: Harvard University Press.

Lee, N. (2013). Childhood and biopolitics: Climate change, life processes, and human futures. Hampshire, UK: Palgrave Macmillan.

Manning, E. (2016). The minor gesture. Durham, NC: Duke University Press. 
Morton, T. (2013). Hyperobjects: Philosophy and ecology after the end of the world. Minneapolis, MN: University of Minnesota Press.

Morton, T. (2016). Dark ecology: For a logic of future coexistence. New York, NY: Columbia University Press.

Negerastani, N. (2008). Cyclonopedia: Complicity with anonymous materials. Melbourne: re.press.

Payne, P. G. (2016). What next? Post-critical materialisms in environmental education. The Journal of Environmental Education, 47(2), 169-178.

Parrika, J. (2015). A Geology of Media. Minneapolis, MN: University of Minnesota Press.

Rousell, D., \& Cutter-Mackenzie, A. (Eds.) (2015). The Changes: Art, research, and writing about climate change by children and young people. Lismore, NSW: Southern Cross University.

Selby, D., \& Kagawa, F. (2010). Runaway climate change as challenge to the 'closing circle' of education for sustainable development. Journal of Education for Sustainable Development. 4(1), pp. 37-50.

Shaviro, S. (2014). The universe of things: On speculative realism. Minneapolis, MN: University of Minnesota Press.

Shaviro, S. (2015). Discognition. London, UK: Repeater Books.

Shepardson, D. P., Niyogi, D., Choi, S., \& Charusombat, U. (2009). Seventh Grade Students' Conceptions of Global Warming and Climate Change. Environmental Education Research, 15(5), 549-570.

Snaza, N., \& Weaver, J. (2015). Introduction: Education and the posthumanist turn. In Snaza, N., \& Weaver, J. (Eds.). Posthumanism and Educational Research (pp. 1-16). New York, NY: Routledge. 
Somerville, M., \& Green, M. (2012). Place and sustainability literacy in schools and teacher education. Paper presented at the AARE, Sydney, NSW.

Steffen,W., Broadgate,W., Deutsch, L., Gaffney, O., \& Ludwig, C. (2015). The trajectory of the Anthropocene: The great acceleration. The Anthropocene Review, 2, 81-98.

Turpin, E., \& Davis, H. (2015). Art \& death: Lives between the fifth assessment \& the sixth extinction. In Davis, H., \& Turpin, E., Art in the Anthropocene: Encounters among aesthetics, politics, environments and epistemologies (pp. 330). London, UK: Open Humanities Press.

Wallin, J.J. (2015). Dark posthumanism, unthinking education, and ecology at the end of the Anthropocene. In Snaza, N., \& Weaver, J. (Eds.). Posthumanism and Educational Research (pp. 134-150). New York, NY: Routledge.

Weaver, J. (2010). Educating the posthuman. Rotterdam, Netherlands: Sense Publishing.

Whitehead, A.N. (1978). Process and Reality. New York, NY: The Free Press.

Woodard, B. (2013). On an ungrounded earth: Toward a new geophilosophy. Brooklyn, NY: Punctum.

Young, E. B. (2013). The Deleuze and Guattari Dictionary. London, UK: Bloomsbury. 